\title{
T. Aubrey Bowen, Oculist, 1837-93: his bequests to English charities
}

\author{
RONALD F. LOWE
}

Melbourne

SUMmaRY Thomas Aubrey Bowen trained as an ophthalmic surgeon in Birmingham, migrated to Australia, and attained the peak of his profession. Since his death in 1893 the Bowen Trust has dispatched annuities to Dr Barnardo's Homes, the University of Birmingham, and the Royal Medical Foundation, Epsom, which to 1981 totalled almost $£ 187850$ or A $\$ 375700$. Further allocations will continue indefinitely.

Thomas Aubrey Bowen was one of the first medically trained oculists to practise in Australia. ${ }^{1}$ Born in Cradley, Worcestershire, he was the third son of a 'dissenting' Unitarian minister, the Reverend William Bowen, MA. His mother, born Marianne Priestley, was a granddaughter of the radical Reverend Joseph Priestley, LLD, FRS, the famous chemist.

Aubrey Bowen began his medical training at Sydenham College and the Birmingham General Hospital, but his studies were interrupted. In 1857 his parents and their 2 youngest sons migrated to Melbourne because of the health of Aubrey and his brother.

Aubrey's health must have improved, as he returned to Birmingham to complete his medical training. He then served for 16 months as resident surgeon to the Birmingham and Midland Counties Eye Hospital before returning to Melbourne (1864), where after 2 years as resident surgeon to the Melbourne Hospital he commenced private practice. ${ }^{1}$ His portrait as a young man is shown in Fig. 1.

He gave prolonged honorary service to the Victorian Eye and Ear Hospital, the Children's Hospital, Melbourne, the Industrial School for unwanted and destitute children, the Medical Society of Victoria, and various governments of the Colony of Victoria. Over the years he rose to the top of his profession. He married a daughter of the Honorable Henry Miller, one of the richest financiers in the colony.

Correspondence to Dr. Ronald Lowe, 82 Collins Street, Melbourne 3000, Australia.
Aubrey Bowen was immersed in all these activities despite some frailty of health, including recurrent asthma. Like numerous medical practitioners of his day he had pulmonary tuberculosis, but was able to withstand the infection until middle age, when his physique declined.

\section{His Will}

When he was aged 54 years his health caused considerable concern, and on 23 March 1892 he made his last will. ${ }^{2}$ Apart from bequests of personal property and small amounts to purchase mementos he directed his trustees to sell his real and residual estate and establish the following annuities: to Marie Belloc, daughter of his cousin $£ 100$ per annum (she died 1948); the home for destitute children known as Dr. Barnardo's Homes, £50 per annum; the Mason Science College in Birmingham, the annual sum of $£ 600$ to found 6 scholarships each of $£ 100$ to be called the first, second, and third Bowen scholarships for the promotion of the study of metallurgy, and civil, mechanical, and electrical engineering; as well as the first, second, and third Priestley scholarships for the study of chemistry. He assigned the balance of the income from the trust to the Royal Medical Benevolent College of Epsom for the benefit of widows and orphans of medical men.

His health failed to improve, so in January of the following year (1893) he left for an extended overseas trip to Europe in the hope of regaining strength and, among other things, to represent the Victorian Government at the International Congress of 


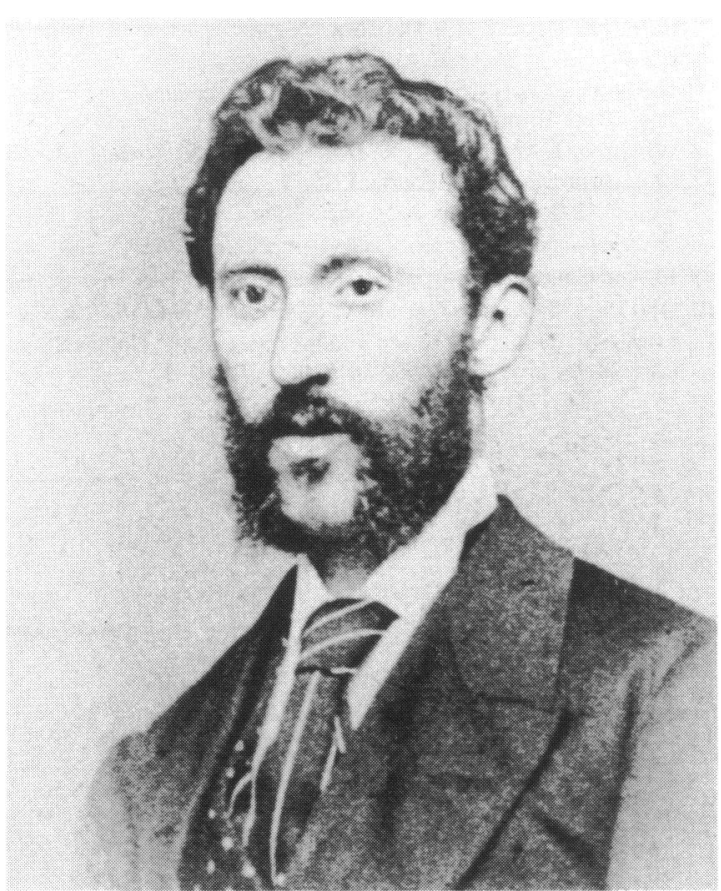

Fig. 1 Thomas Aubrey Bowen.

Medicine in Rome.$^{1} \mathrm{He}$ spent some time in Cairo, where he felt much better; then he proceeded to Naples. But unfortunately while there he contracted a form of influenza and his condition deteriorated rapidly. Sensing a grave outcome he added a codicil to his will bequeathing to his wife the sum of $£ 20000$ to be divided by her among charitable and benevolent institutions in Victoria. He was anxious to reach England but arrived there sinking fast, and died of pulmonary phthisis in London on 27 July 1893.

On 16 March 1894 his executors applied for probate on his estate ${ }^{3}$ to the full net value of $£ 6599210$ s $11 d$. Of this approximately $£ 45000$ was available to provide the annuities to be sent to England. Since then the Thomas Aubrey Bowen Trust has been administered by Melbourne solicitors. By careful management and despite annual disposal of interest over 86 years the invested capital of the trust fund in June 1980 stood at 84400 Australian dollars.

Up till 1981 Dr Barnardo's ${ }^{4}$ had received from the Bowen Trust a total of $£ 4350$ or $A \$ 8700$. Originally the annuity probably sufficed for the support of 4 to 6 children.

Aubrey Bowen was proud of both his father's and his mother's families, so he founded the Bowen and Priestley scholarships in their honour. These forebears were radical, free thinking dissenters, and even though Aubrey Bowen had married according to the rites of the Church of England he probably chose the new Mason Science College ${ }^{5}$ for endowment of these memorial scholarships as being more appropriate than Queen's, which had absorbed his Alma Mater (Sydenham). In 1900 Queen's and Mason Colleges were in turn amalgamated to form the University of Birmingham, ${ }^{6}$ so the Bowen and Priestley scholarships were transferred to the university, to which the annuities are still remitted.

Originally each scholarship provided support for one year's postgraduate investigations, but, as the stipends were fixed, inflation has reduced them to amounts of little significance. They are now awarded after long intervals or are added to other funding; but over the years the Bowen Trust has contributed $£ 52200$ or $\mathbf{\$} \$ 104400$ for these scholarships.

The Royal Medical Foundation remains an integral administrative section of Epsom College ${ }^{78}$ and provides foundation scholarships and bursaries to the needy sons and daughters of doctors. Assistance ranges from the full cost of attending the college (foundation scholarships) down to bursaries of $£ 600$ per annum.

For the financial year 1980 the Bowen Fund contributed $£ 4213$ or a little over $25 \%$ of the income of the foundation, being only exceeded by $£ 6800$ from the British Medical Association's Charities Committee. ${ }^{9}$

As the annuity is not of fixed amount, and owing to careful management of capital by the trustees, the amounts provided have suffered less from inflation than have the other endowments. Up to 1981 the Royal Medical Foundation had received $£ 131300$ or A $\$ 262600$ from the Bowen Trust.

\section{Conclusions}

The Bowens had no children, but in 1883 their nextdoor neighbour, William Garrard, MRCSEd, ${ }^{10}$ died a week after his wife, leaving 4 children. Aubrey Bowen took the 4 orphans into his house and made them his wards. ${ }^{.1}$

Bowen saw many deserted and destitute children at the Industrial School, Melbourne, and very many children in distress over the years he attended the Victorian Eye and Ear Hospital and the Children's Hospital, Melbourne. It is apparent that he shared the same humanity and idealism as Dr Thomas Barnardo, Sir Josiah Mason, and Dr John Propert, who founded the charitable institutions mentioned in his will. The major part of his estate was bequeathed to assist children in need.

Founded in 1893, the Bowen Trust had a capital value of $A \$ 84400$ in 1980 , and in 87 years has contributed almost $£ 187850$ or $A \$ 375700$ for the support of young people. 
Dr R. J. Hetherington, of Bịmingham, England, gave extensive help with inquiries to the institutions in England, and Messrs. Moule Hamilton and Derham, of Melbourne, provided much detail of disbursements from the Thomas Aubrey Bowen Trust.

\section{References}

1 Lowe RF. T Aubrey Bowen, oculist, 1837-93. Aust J Ophthalmol 1981; 9: 155-62.

2 Will of Thomas Aubrey Bowen, Public Record Office, Melbourne.

3 Probate papers. Thomas Aubrey Bowen, Public Record Office, Melbourne.
4 Barnardo Review 113. Hertford, Barnardo School of Printing, 1981.

5 Mason University College, Birmingham. Calendar for the Session 1899-1900. Birmingham: Cornish Bros, 1899.

6 Whybrow J, Waterhouse R. How Birmingham Became a Great City. Birmingham: Whybrow, 1976.

7 Epsom College-Aims and Constitution.

8 An Introduction to Epsom College. A brochure.

9 Epsom College. Report of the Council, 1981.

10 Obituary. Mr William Garrard MRCSE. Aust Med J 1883; 5: 175.

11 Lowe RF. T Aubrey Bowen and his house at 167 Collins Street East, Melbourne. Aust NZ J Surg 1981; 51: 102-5. 